\title{
PEMBERDAYAAN KELOMPOK PEMUDA GMIT DAN MASYARAKAT SEHAMPARAN MELALUI INTENSIFIKASI USAHA DI PEKARANGAN
}

\author{
Obed Haba Nono*, Johanis Ly *, Agust R. Riwu *, J. F. Theedens*, Yulianus Linggi ** \\ *Prodi Ilmu Peternakan Fakultas Peternakan \\ **Prodi Budidaya Perairan Fakultas Kelautan dan Perikanan Universitas Nusa Cendana Kupang \\ e-mail : obedhaba@gmail.com
}

\begin{abstract}
ABSTRAK
Adapun tujuan dari kegiatan ini adalah untuk : (1) meningkatkan produksi dan produktivitas usaha ternak (babi, dan ayam buras), pertanian/tanaman organik dan ikan air tawar di pekarangan; (2) meningkatkan sanitasi / pengendalian lingkungan dari polusi limbah organik / kandang dan limbah anorganik seperti plastik, kertas dan lainnya; (3) meningkatkan keterampilan dan atau pendapatan mitra. Luaran yang dihasilkan dari Program IbM ini adalah pada: (1) Aspek produksi: (a) aneka produk hasil olahan sampah plastik, kebersihan/kesehatan lingkungan, (b) ternak babi yang bermutu lebih sehat dan produktif, (c) Usaha tani/tanaman pekarangan: aneka sayur organik (kangkung, sawi, bayam, bawang, tomat) dan ikan lele; (2) Aspek manajemen : Mitra lebih mampu dalam menata : (a) kebersihan/kesehatan lingkungan (b) pengendalian kesehatan ternak, (d) pembuatan dan aplikasi pupuk organik, pestisida nabati, pertanian vertical, mesin tetas, serta pemanfaatan pekarangan yang lebih optimal/produktif Metode yang diterapkan adalah pelatihan dan demoplot dari setiap inovasi/teknologi yang ditawarkan, yaitu pengolah limbah an organik (terutama plastik), instalasi kandang, mesin tetas, pengendalian kesehatan ternak. dan pemanfaatan limbah kandang untuk pembuatan pupuk organik, pesitisida nabati dan aplikasinya kepada tanaman, pertanian vertikal serta pembuatan kolam terintegrasi dengan sayuran di pekarangan. Kegiatan selanjutnya adalah pendampingan. Lama kegiatan selama 6 bulan.

Hasil kegiatan berupa sejumlah produk meliputi : ternak ayam / babi bermutu, pupuk organik
\end{abstract}


(padat) dan pestisida nabati. Hasil berupa pupuk organik, pestisida nabati untuk aneka sayuran organik. Kesimpulan : Manfaat dari penerapan aneka teknologi tepat guna pada sejumlah cabang usaha di pekarangan menunjukkan : (1) hasil pupuk organik meningkatkan produksi sebesar (30-100\%) efisiensi input dari : pupuk (40-50\%), waktu panen lebih cepat untuk sayur organik (16-20\%), (2) efisiensi pestisida kimiawi Dari penerapan pestisida nabati mencapai 60-100\%; (3) Hasil perkandangan ayam buras sanggup meningkatkan produktivitas sebesar 3-4 kali lipat dari 3-4 ekor menjadi 18-20 ekor anak selama selama bulan pertama setelah menetas , (4) aplikasi teknologi mesin tetas berdampak kepada efisiensi waktu dan produktivitas dan mutu ayam meningkat (s/d 300\%); (5) kesehatan ternak babi dan anjing meningkat, 6) aneka hasil kerajinan dari pengolahan sisa/limbah plastik berupa asbak, tempat tisu, tas, keranjang sayur dan lain sebagainya dan 7) ternak ikan dan aneka sayuran hasil intgerasi dalam sistem aquaponik . Kata kunci : Aquaponik, Limbah, Mesin Tetas, Pestisida Nabati , Pupuk Organik

\section{PENDAHULUAN}

Optimalisasi pemanfaatan sumber daya merupakan salah satu solusi dalam kerangka peningkatan kesejahteraan masyarakat. Dalam konteks pembangunan masyarakat perkotaan maka optimalisasi sumber daya lahan dalam hal ini usaha pekarangan merupakan salah satu solusi yang strategis. Dikatakan demikian selain mudah dipantau, juga akan memberikan nuansa estetika, ergonomis serta berpotensi besar dalam meningkatkan income pemilik selain meningkatkan kenyamanan lingkungan. Menurut Siregar dan Wahyuni (2018) budaya pemanfatan pekarangan semakin tinggi karena dapat sebagai sumber pangan (aneka sayuran) dan budaya bertanam sayuran di pekarangan ternyata juga disukai kalangan ibu rumah tangga di daerah perkotaan.

Daerah perkotaan ada yang sama sekali tidak memiliki lahan pekarangan maka bertanam sayuran melalui teknik tertentu seperti vertikultur. Tujuan dari pemanfaatan pekarangan berapapun luasannya akan memberikan hasil yang optimal termasuk di dalamnya sistem aquaponik yang bermanfaat sehingga mampu menghasilkan sayuran dan ikan yang dapat memenuhi kebutuhan rumah tangga maupun komersil yang dapat menghasilkan keuntungan.

Sebagai mitra adalah Kelompok Pemuda, GMIT merupakan salah satu badan pembantu 
pelayanan di gereja yang memiliki tupoksi untuk meningkatkan pemahaman terhadap pelayanan (iman) dan kegiatan keeterampilan (life skills). Life skills ini nantinya sebagai aset utama dalam pengembangan diri sebagai individu maupun kelompok. Dalam pada itu, masyarakat sehamparannya termasuk ibu-ibu dan anak-anak disekitarnya seyogyanya diberdayakan melalui penerapan IPTEKS yang dimiliki kampus. Kelompok lainnya seperti Perempuan GMIT bertugas untuk pemberdayaan ibu-ibu di lingkungan jemaat atau masyarakat sekitarnya. Adapun potensi yang dimiliki adalah dengan jumlah sekitar 300-an pemuda, dan 100-an ibu-ibu dalam kerangka pemberdayaan sebenarnya sangat berpotensi dalam meningkatkan kegiatan-kegiatan produktif. Hal ini akan bermuara kepada peningkatan skill diantara mereka serta masyarakat sekitarnya. Selain itu, dengan adanya keragaman usaha produktif yang dimiliki masyarakat sehamparan sangat tinggi, maka potensinya akan lebih tinggi dalam mendukung kesejahteraan dan mutu kehidupan keluarga dan jemaat serta masyarakat sekitarnya.

Penentuan mitra didasarkan pada hasil diskusi mendalam, observasi serta kesekapatan dalam penentuan jenis teknologi dan penataan usaha berdasarkan masalah krusial / struktural yang dihadapi mtra. Kelompok Pemuda GMIT jemaat Gereja Diaspora dan masyarakat mitra mereka berada di Kelurahan Oesapa, wilayah Oesapa bagian Timur, sekaligus merupakan masyarakat lingkar kampus. Adapun usaha yang dilakoni oleh mitra (sehamparan lingkar kampus) adalah jualan makanan / minuman, usahatani ternak dan pengolahan limbah/sampah.

\section{MASALAH}

Berdasarkan analisis situasi serta hasil diskusi intens dengan pengurus /anggota kelompok, dan aparat di wilayah tersebut, ditemukan masalah umum yaitu masih rendahnya keterampilan mitra dalam hal penguasaan teknologi yang menjamin intensifikasi sejumlah cabang usaha serta yang ramah lingkungan pekarangan. Hasil perumusan selanjutnya ditemukan 2 masalah khusus yaitu 1) Permasalahan teknis meliputi : i) Untuk pengolahan limbah/sampah yang sulit terurai (sampah bahan baku plastik,kertas dan lainnnya) ketersediaan bahan baku dan desainnya masih terbatas. Hal ini akan berdampak kepada potensi dampak polusi yang tetap akan semakin meningkat; ii) Produksi dan produktivitas aneka usaha ternak masih rendah. Hal ini disebabkan oleh sistem produksi yang belum baik, serta penanganan limbah yang ekstensif. Ke-extensifan 
ini berkaitan erat dengan penguasaan ilmu pengetahuan dan teknologi produksi dan atau pengolahan limbah yang masih rendah sehingga belum memberikan manfaat optimal kepada usahatani lainnya dengan prinsip integrasi; iii) Potensi polusi limbah dari usaha peternakan yang merupakan usaha pekarangan yang akan semakin tinggi; iv) Potensi pekarangan sebagai basis usaha ternak ikan terintegrasi dengan aneka sayur dapat menjadi salah satu usaha andalan terutama bagi pemenuhan kebutuhan keluarga akan gizi.; 2) Permasalahan manajemen usaha yaitu: i) Perencanaan usaha meliputi penentuan skala usaha, perencanaan produksi, dan pemasaran masih sederhana sehingga kurang respon terhadap permintaan pasar yang amat besar; ii) Aspek sumber daya manusia, yaitu belum ada tenaga teknis yang dapat mendampingi kelompok tersebut dalam menerapkan prinsip-prinsip penanganan kesehatan ternak (babi, anjing dan ayam) yang mampu meningkatkan produktivitas usaha dan pencegahan penyakit zoonosis; iii) Pananganan limbah terutama limbah organik melalui pembuatan pupuk organik belum intensif sementara risiko polusi sangat besar; iv) Manajemen produksi /pengadaan bahan baku dan pemasaran hasil olahan limbah/sampah masih terbatas; v) Belum adanya usaha ikan air tawar (kolam) yang diintegrasikan dengan aneka sayuran.

Berdasarkan uraian di atas, tujuan kegiatan tersebut adalah untuk meningkatkan:

(1) keterampilan mitra dalam penataan dagangan, budidaya aneka usahatani ternak dan ikan, pengolahan limbah sehingga menghasilkan kegiatan-kegiatan yang ramah lingkungan;

(2) produksi/produktivitas atau efisiensi usaha termasuk usaha dagangan makanan, aneka sayuran, ikan, ternak ayam buras dan ternak babi.

\section{METODE PELAKSANAAN}

Kegiatan PKM dilaksanakan pada mitra sejak bulan April sampai dengan September 2018. Dengan durasi kegiatan \pm 6 bulan. Adapun tahapan kegiatan meliputi tahapan persiapan dan pelaksanaan. Tahapan persiapan meliputi : penentuan mitra, kesepakatan tentang teknologi (alat dan bahan yang dibutuhkan), waktu pelaksanaan berdasarkan jenis kegiatan .

1. Tahap persiapan meliputi :

a) Penentuan responden/mitra.- Pada penentuan mitra didasarkan kepada sejumlah observasi, diskusi mendalam terhadap sejumlah pihak seperti aparat (terutama Lurah, 
RT,RW, PPL, tokoh masyarakat lainnya) sebagai narasumber. Akhirnya ditentukan mitra berupa kelompok Pemuda GMIT Diaspora serta masyarakat sehamparan serta penentuan lokasi dan tempat demoplot IPTEKS yang akan diaplikasikan.

b) Bahan dan alat yang digunakan dalam Penerapan IPTEKS.

Adapun bahan dan alat yang dibutuhkan/digunakan dalam setiap IPTEKS mulai dari pembuatan sampai dengan penerapannya tertera pada Tabel 1.

Tabel 1. Jenis IPTEKS, alat dan bahan, spesifikasi dalam penerapan IPTEKS

\begin{tabular}{|c|c|c|c|c|c|}
\hline No & Jenis Ipteks & $\begin{array}{l}\text { Alat Dan Bahan } \\
\text { Yang Digunakan }\end{array}$ & $\begin{array}{c}\text { Spesifikasi } \\
\text { Alat }\end{array}$ & $\begin{array}{c}\text { Cara } \\
\text { Mengukurnya }\end{array}$ & Keterangan \\
\hline 1 & $\begin{array}{l}\text { Perkan- } \\
\text { dangan }\end{array}$ & $\begin{array}{l}\text { Kayu, seng, paku, } \\
\text { cat, amplas, } \\
\text { hamar, gunting } \\
\text { seng }\end{array}$ & $\begin{array}{l}2 \text { buah, } \\
\text { masing-masing } \\
2 \text { lantai sehing- } \\
\text { ga terdapat } 4 \\
\text { kotak }\end{array}$ & $\begin{array}{l}\text { Pemisahan anak dari } \\
\text { induk atau mesin } \\
\text { tetas }\end{array}$ & - \\
\hline 2 & Mesin tetas & $\begin{array}{l}\text { Triplex, kayu } \\
\text { usuk, thermostat, } \\
\text { termometer, kaca, } \\
\text { sekam padi (untuk } \\
\text { alas dinding } \\
\text { mesin) }\end{array}$ & $\begin{array}{l}1 \text { buah } \\
\text { Kapasitas } 50 \\
\text { butir }\end{array}$ & $\begin{array}{l}\text { Pencatatan setiap } \\
\text { telur yang ditetaskan }\end{array}$ & $\begin{array}{l}\text { Efisiensi waktu tentu } \\
\text { akan sangat tinggi } \\
\text { karena penanfaatan } \\
\text { mesin akan maksimum } \\
\text { dengan manfaatkan telur } \\
\text { dari luar selain yang } \\
\text { dihasilkan anggota }\end{array}$ \\
\hline 3 & $\begin{array}{l}\text { Pupuk } \\
\text { organik/ } \\
\text { bokashi }\end{array}$ & $\begin{array}{l}\text { Limbah kandang } \\
\text { ternak (babi, sapi, } \\
\text { ayam potong), } \\
\text { EM4, gula } \\
\text { pasir/air, ember, } \\
\text { terpal, sekop, } \\
\text { karung }\end{array}$ & $\begin{array}{l}\text { Kapasitas 300- } \\
500 \mathrm{~kg}\end{array}$ & $\begin{array}{l}\text { Pengukuran } \\
\text { terhadap berat, dan } \\
\text { interval waktu } \\
\text { panen dari aneka } \\
\text { sayuran seperti sawi, } \\
\text { bayam dan } \\
\text { kangkung }\end{array}$ & $\begin{array}{l}\text { Produktivitas aneka } \\
\text { tanaman akan meingkat } \\
\text { sekaligus ramah } \\
\text { lingkungan }\end{array}$ \\
\hline 4 & $\begin{array}{l}\text { Pestisida } \\
\text { Nabati }\end{array}$ & $\begin{array}{l}\text { Aneka dedaunan, } \\
\text { tembakau, cabe } \\
\text { detergen, minyak } \\
\text { goreng bekas }\end{array}$ & $\begin{array}{l}\text { Kapasitas/ } \\
\text { wadah } 5 \text { liter }\end{array}$ & $\begin{array}{l}\text { Pengukuran } \\
\text { terhadap tingkat } \\
\text { serangan hama } \\
\text { sebelum dan setelah } \\
\text { penyemprotan }\end{array}$ & $\begin{array}{l}\text { Pengurangan } \\
\text { penggunaan/ pembelian } \\
\text { pestisida kimiawi }\end{array}$ \\
\hline 5 & $\begin{array}{l}\text { Kesehatan } \\
\text { ternak }\end{array}$ & $\begin{array}{l}\text { Obat dan alat } \\
\text { suntik }\end{array}$ & $\begin{array}{l}\text { Sesuai } \\
\text { kebutuhan }\end{array}$ & $\begin{array}{l}\text { Berdasarkan dosis } \\
\text { dari setiap jenis } \\
\text { tindakan (preventif/ } \\
\text { kuratif) }\end{array}$ & $\begin{array}{l}\text { Ternak ayam, anjing } \\
\text { dan babi lebih sehat }\end{array}$ \\
\hline 6 & $\begin{array}{l}\text { Budidaya ikan } \\
\text { (aqua kultur) }\end{array}$ & $\begin{array}{l}\text { Kolam, ikan dan } \\
\text { tanaman sayuran } \\
\text { (terutama } \\
\text { kangkung) }\end{array}$ & $\begin{array}{l}\text { Kapasitas } 1000 \\
\text { ekor ikan }\end{array}$ & $\begin{array}{l}\text { Pengukurna } \\
\text { terhadap produksi } \\
\text { ikan dan kangkung }\end{array}$ & $\begin{array}{l}\text { Efisiensi penggunaan } \\
\text { pupuk untuk sayuran } \\
100 \%\end{array}$ \\
\hline
\end{tabular}

\section{Tahapan Pelaksanaan.}

Pelaksanaan PKM atau penerapan IPTEKS kepada mitra melalui : pelatihan, demplot, monitoring dan evaluasi /pendampingan (termasuk di dalamnya adalah cara pengumpulan data). Uraian pelaksanaannya sebagai berikut : 
a. Pelatihan disampaikan dalam bentuk ceramah dan diskusi, dengan sejumlah materi oleh tim pelaksana, sejumlah 21 orang peserta dari kelompok, ditambah dengan masyarakat sehamparan dan mahasiswa atau alumni sehingga mencapai 36 orang yang dilakukan selama 3 hari. Menjadi sasaran kegiatan adalah anggota kelompok (mitra), dan masyarakat sehamparan dan lainnya (terutama ibu-ibu rumah tangga).

b. Pembuatan pengolahan limbah terutama plastik sebaga bahan baku aneka handy craft seperti tempat tisu atau tas dan lain sebagainya.

c. Melakukan instalasi teknologi mesin tetas.

d. Demonstrasi (percontohan) pengolahan limbah ternak babi dan ayam menjadi pupuk organik (bokashi)

e. Penerapan mesin penetasan telur yang memperlihatkan partisipasi sejumlah anggota dengan memasukkan telur dalam mesin tetas

f. Pembuatan pesitisda nabati yang diikuti oleh semua peserta

g. Kegiatan penanganan kesehatan ternak terutama ternak ayam, anjing atau babi

h. Pembuatan kolam ikan yang diintegrasikan dengan aneka sayuran (terutama kangkung)

Dalam pada itu, rancangan evaluasi terutama terhadap tingkat partisipasi, dan konsistensi mitra dan kelompok sehamparan dalam menerapkan atau memanfaatkan IPTEKS yang diinjeksikan.

\section{Cara Pengumpulan dan Analisis Data.}

Adapun cara pengumpulan data dan analisis data tertera pada Tabel 2.

Tabel 2. Cara Pengumpulan dan Analisis data berdasarkan Ipteks yang diinjeksikan 


\begin{tabular}{|c|c|c|c|c|}
\hline No & Uraian *) & Pengumpulan & Analisis & Keterangan Pengukuran \\
\hline 1 & Perkandangan & $\begin{array}{l}\text { Pencatatan volume, } \\
\text { ukuran dan kapasitasnya }\end{array}$ & $\begin{array}{l}\text { Kepadatan, } \\
\text { kenyamanan DOC }\end{array}$ & $\begin{array}{l}\text { Aman dan nyaman dari pengaruh } \\
\text { lingkungan (cahaya matahari, } \\
\text { predator) }\end{array}$ \\
\hline 2 & Mesin Tetas & $\begin{array}{l}\text { Pencatatan jumlah telur } \\
\text { (ditetaskan, dan yang } \\
\text { menetas) }\end{array}$ & $\begin{array}{l}\text { \%penetasan }=\{\text { (telur } \\
\text { ditetaskan }- \\
\text { menetas }) / \text { telur } \\
\text { ditetaskan }\} \times 100 \%\end{array}$ & $\begin{array}{l}\text { Tingkat penetasan bervairiasi } \\
\text { tergantung kefertilan dari telur, } \\
\text { perkembangan populasi, }\end{array}$ \\
\hline 3 & Pupuk organik & $\begin{array}{l}\text { Pengukuran bobot bahan } \\
\text { dan hasil }\end{array}$ & Rata-rata & $\begin{array}{l}\text { Berdasarkan volume (karung) } \\
\text { yang diaplikasikan }\end{array}$ \\
\hline 4 & Pestisida Nabati & Pengukuran volume hasil & Rata -rata & $\begin{array}{l}\text { Berdasarkan volume dan } \\
\text { frekuensi aplikasi }\end{array}$ \\
\hline 5 & $\begin{array}{l}\text { Produksi } \\
\text { sayuran }\end{array}$ & $\begin{array}{l}\text { Pengukuran interval } \\
\text { panen, bobot per satuan } \\
\text { luas }\left(\mathrm{m}^{2}\right)\end{array}$ & $\begin{array}{l}\text { Rata }- \text { rata }=\text { bobot } \\
\text { panen/Luas panen }\end{array}$ & $\begin{array}{l}\text { Untuk produksi tanaman lainnya } \\
\text { belum dihitung secara rinci }\end{array}$ \\
\hline 6 & $\begin{array}{l}\text { Penanganan } \\
\text { penyakit ternak }\end{array}$ & $\begin{array}{l}\text { Pencatatan jenis dan dosis } \\
\text { obat berdasarkan priode } \\
\text { tumbuh ternak }\end{array}$ & - & $\begin{array}{l}\text { Jenis dan dosis obat tergantung } \\
\text { kondisi ternak babi, ayam dan } \\
\text { anjing }\end{array}$ \\
\hline 7 & $\begin{array}{l}\text { Integrasi Kolam } \\
\text { dengan sayuran } \\
\text { (aquakultur) }\end{array}$ & $\begin{array}{l}\text { Produksi sayuran dan } \\
\text { ikan }\end{array}$ & $\begin{array}{l}\text { Rata }- \text { rata }=\text { bobot } \\
\text { panen/Luas panen }\end{array}$ & Berat bersih \\
\hline
\end{tabular}

Catatan : *) Uraian efektifitas dan efisiensi IPTEKS

\section{Pendampingan, Monitoring dan Evaluasi}

Kegiatan tersebut bertujuan untuk memerikan dukungan langsung , bimbingan maupun konsultasi teknis maupun manajemen usaha berkaitan dengan adopsi dan keberlanjutan penerapan sejumlah teknologi yang diinjeksikan dalam kegiatan pelatihan/demplot. 


\section{HASIL YANG DICAPAI}

\section{Hasil kegiatan dapat dilihat pada Tabel 3.}

\section{Tabel 3. Dampak/Hasil Kegiatan Penerapan Teknologi Tepat Guna pada usaha Mitra}

\begin{tabular}{|c|c|c|c|c|c|c|}
\hline No & Teknologi & Uraian & Sebelum & Sesudah & Peningkatan & Keterangan \\
\hline \multirow[t]{3}{*}{1} & \multirow{3}{*}{ Pupuk organik } & \multicolumn{5}{|c|}{ Efisiensi Produksi sayuran } \\
\hline & & -produksi/hari & $0-5 \mathrm{~kg}$ & $30-50-\mathrm{kg} /$ & $30-100 \%$ & $\begin{array}{l}\text { Sayuran kangung, } \\
\text { sawi, , cabe dan } \\
\text { bayam }\end{array}$ \\
\hline & & -efisiensi pupuk & Tidak ada & Tinggi & $40-50 \%$ & \\
\hline \multirow[t]{4}{*}{2} & \multirow[t]{4}{*}{ Pestisida nabati } & -efisiensi obat & tidak & Tinggi & $60-100 \%$ & \\
\hline & & $\begin{array}{l}\text {-bahan pangan } \\
\text { sehat }\end{array}$ & tidak & sehat & Tinggi & organik \\
\hline & & -daya simpan & singkat & Lebih lama & Sedang-tinggi & \\
\hline & & Ramah lingkungan & Tidak & Ramah & tinggi & $\begin{array}{l}\text { Termasuk aman } \\
\text { bagi kesehatan }\end{array}$ \\
\hline 3 & Perkandangan & $\begin{array}{l}\text { Mortalitas anak } \\
\text { ayam bulan } \\
\text { pertama }\end{array}$ & $80-100 \%$ & $0-5 \%$ & Produksi 3-4x & $\begin{array}{l}\text { Kapasitas kandang } \\
18-20 \text { ekor }\end{array}$ \\
\hline \multirow[t]{4}{*}{4} & \multirow[t]{4}{*}{ Mesin tetas } & Jenis ras ayam & lokal & Unggul & & $\begin{array}{l}\text { Kampung diganti } \\
\text { Bangkok atau } \\
\text { turunan/sejenisnya }\end{array}$ \\
\hline & & Produksi anak /thn & $2-4 x$ & $\begin{array}{l}\text { Setiap } \\
\text { waktu }\end{array}$ & & $\begin{array}{l}\text { Dengan mesin } \\
\text { tetas maka } \\
\text { menjadi fleksibel } \\
\text { dalam penetasan }\end{array}$ \\
\hline & & Kandang anak & Tidak ada & ada & 3 buah & \\
\hline & & Populasi ayam & Rendah & cukuptinggi & $20-60 \%$ & \\
\hline 5 & $\begin{array}{l}\text { Penanganan } \\
\text { kesehatan } \\
\text { ayam,anjing \& } \\
\text { Ternak babi }\end{array}$ & $\begin{array}{l}\text { Penanganan } \\
\text { kesehtan dan } \\
\text { reproduksi }\end{array}$ & sederhana & Lebih baik & $30-45 \%$ & \\
\hline 6 & $\begin{array}{l}\text { Pengolahan } \\
\text { limbah plastik }\end{array}$ & produksi & Tidak ada & $\begin{array}{l}\text { Ada dengan } \\
\text { disain } \\
\text { menarik } \\
\text { untuk asbak } \\
\text { dan tas } \\
\text { dsbnya } \\
\end{array}$ & $100 \%$ & $\begin{array}{l}\text { Sebelum kegiatan } \\
\text { tidak ada yang bis } \\
\text { a mengolah } \\
\text { menjadi aneka } \\
\text { handy craft }\end{array}$ \\
\hline 7 & $\begin{array}{l}\text { Integrasi kolam } \\
\text { dengan aneka } \\
\text { sayuran }\end{array}$ & produksi & Tidak ada & ada & $100 \%$ & $\begin{array}{l}\text { Potensi } \\
\text { pengembangan } \\
\text { besar }\end{array}$ \\
\hline 8 & Respon mitra & Kehadiran & - & tinggi & $100 \%$ & Partisipasi aktif \\
\hline
\end{tabular}


Adapun gambaran secara ringkas tentang produk kegiatan PKM tersebut adalah tertera pada Ilustrasi 1.

Teknologi pemanfataan pupuk limbah kandang babi dan ayam potong/buras milik mitra (sebagai bahan baku pembuatan pupuk organik), limbah dedaunan sebagai bahan baku pestisida nabati, instalasi mesin tetas, brooder, kolam untuk integrasi ikan dengan aneka tanaman, pembuatan pertanaman sayuran dengan berbagai bentuk wadah

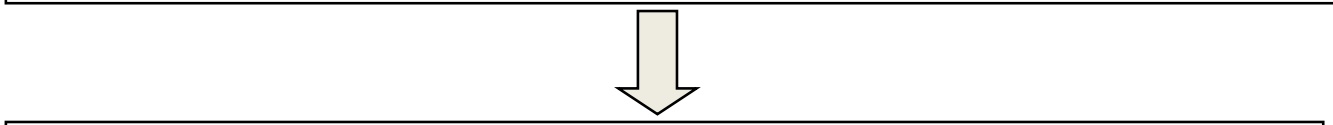

Pupuk organik, pestisida nabati, pertanaman aneka sayuran dalam berbagai wadah (polybag, bekas karung semen, paralon /pertanian vertical, mesin tetas dan anak ayam buras yang diseleksi (masih proses penetasan pengeraman), kolam sistem aquaponik /integrasi dengan aneka sayuran (masih proses pemeliharaan)

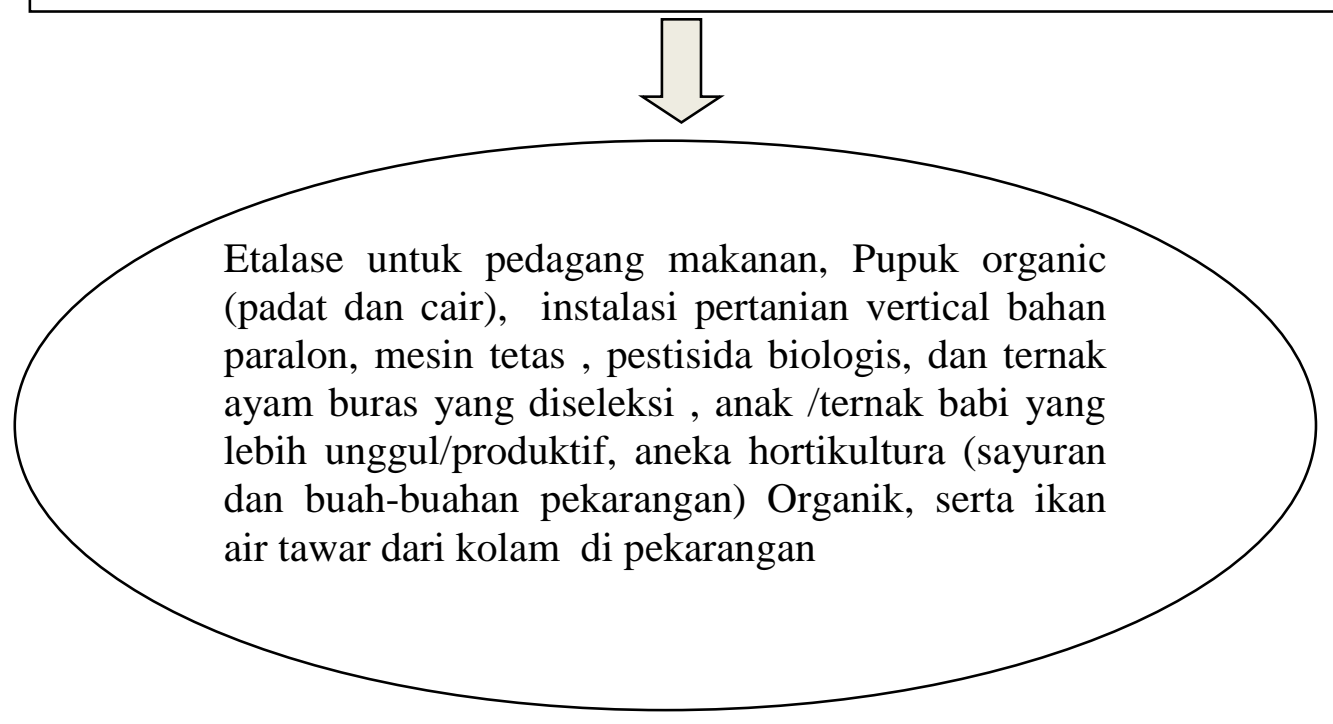

Ilustrasi 1. Produk Pengabdian PKM Bagi Mitra 
Adapun gambaran produk PKM sebagai berikut:

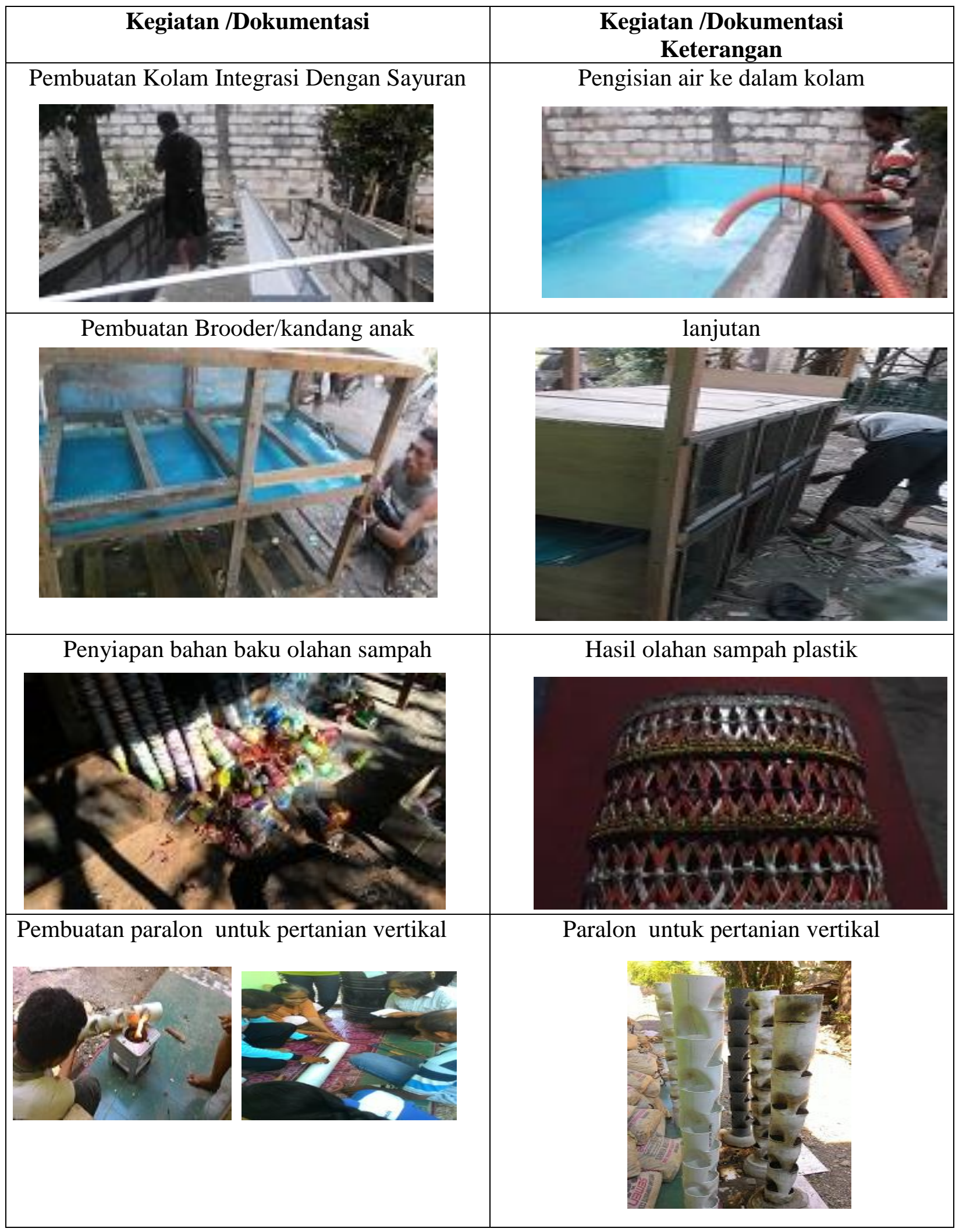




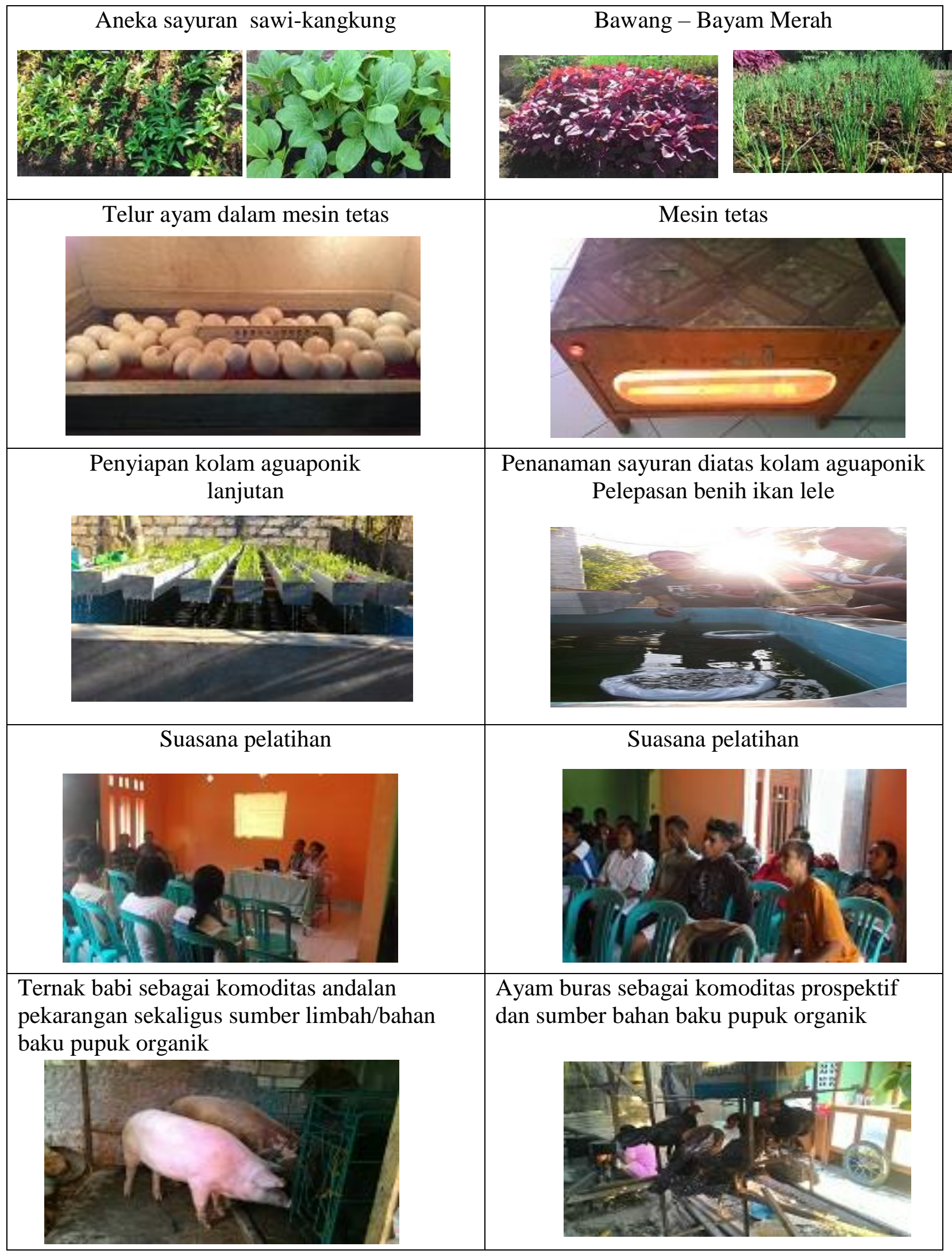




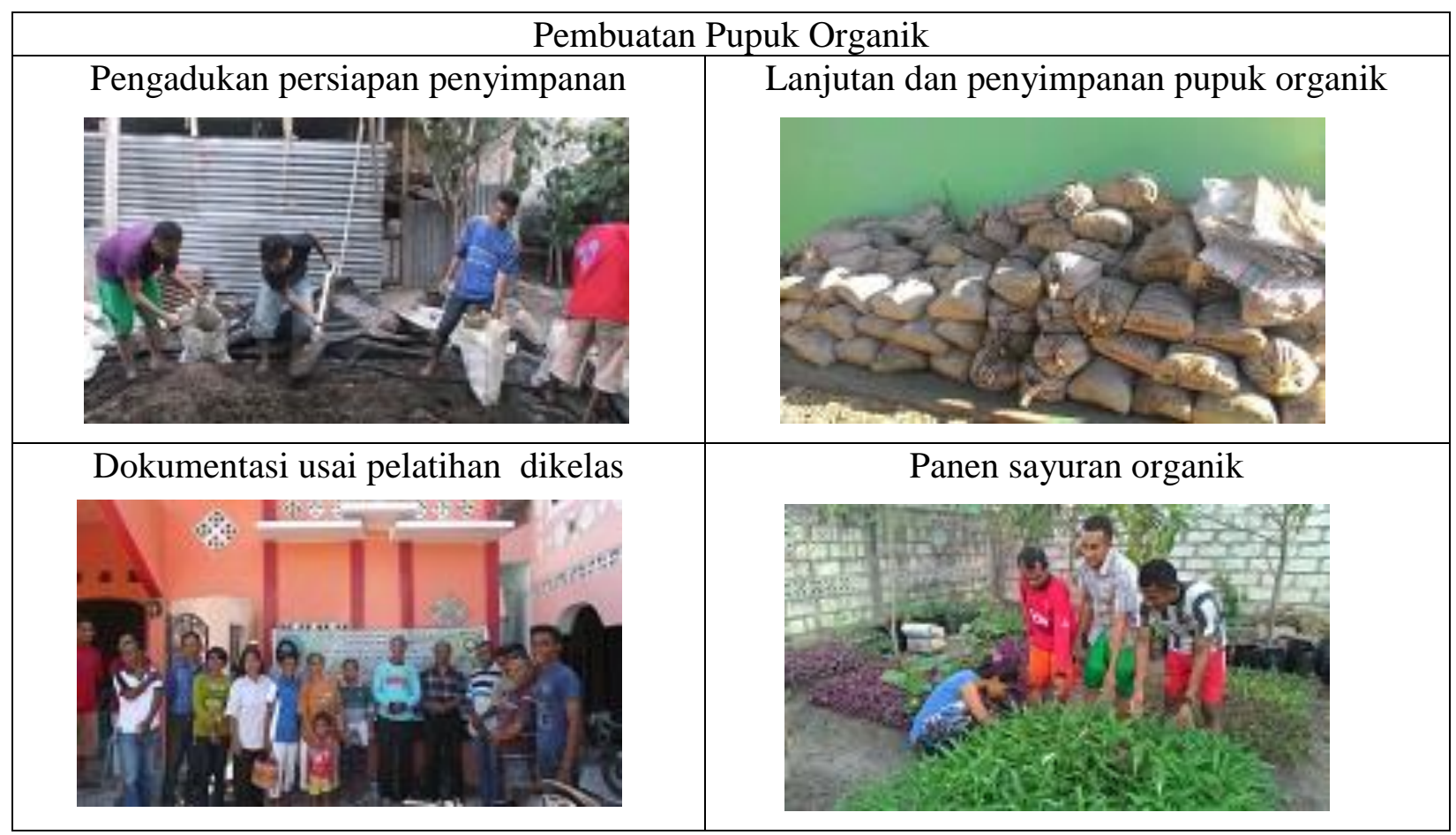

\section{IMPLIKASI TEMUAN}

Berdasarkan dampak positif secara ekonomis dan non ekonomis di atas dan hasil pengamatan dan diskusi bersama mitra diperoleh gambaran bahwa;

1. Program Kemitraan Masyarakat tentang penyuluhan, pendampingan dan pelatihan dapat meningkatkan pengetahuan dan keterampilan dalam berusaha terutama dalam optimaliai pekarangan berdampak selain kepada peningkatan produktivitas dan kemampuan memenuhi permintaan pasar yang selalu meningka, tetap juga mengurani dampak limbah terhadap lingkungan.

2. Animo dan keaktifan peserta untuk berinovasi dalam pengolahan limbah dan pemanfataannya dengan prinsip integrasi usahatani dengna ikan akan lebih optimal/maksimal dan berkelanjutan.

3. Masih diperlukan pendampingan untuk memfasilitasi mereka dalam berbagai hal peningkatan produktivitas usaha. 
Hal ini sesuai dengan profil .potret permasalahan lain yang terekam adalah:

(1) Sumber Daya Manusia ( SDM ) dengan tingkat pendidikan yang relatif tinggi namun penguasaan teknologi dalam penataan usaha di pekarangan masih terbatas;

(2) perhatianpemilik/mitra terhadap potensi pekarangan yang dapat cukup besar belum optimal

(3) Masih sering terjadi wabah penyakit ternak terutama ternak babi dan ayam buras sehingga menjadi tantangan tersendiri bagi Tim pelaksana dalam menfasilitasi mitra dan masyarakat sehamparan dan sekitarnya.

(4) Perilaku petani dalam penggunaan pupuk dan pestisida nabati sudah semakin meningkat. .

(5) Sumber pendanaan seperti lembaga keuangan mikro untuk memfasilitasi mereka dalam pemanfataan potensi lahan pekarangan belum ada.

\section{KESIMPULAN DAN SARAN}

\section{Kesimpulan}

Manfaat dari penerapan aneka teknologi tepat guna pada sejumlah cabang usaha di pekarangan menunjukkan : (1) hasil pupuk organik meningkatkan produksi sebesar (30-100\%) efisiensi input dari : pupuk (40-50\%), waktu panen lebih cepat untuk sayur organik (16-20\%), (2) efisiensi pestisida kimiawi Dari penerapan pestisida nabati mencapai 60-100\%; (3) Hasil perkandangan ayam buras sanggup meningkatkan produktivitas sebesar 3-4 kali lipat dari 3-4 ekor menjadi 18-20 ekor anak selama selama bulan pertama setelah menetas, (4) aplikasi teknologi mesin tetas berdampak kepada efisiensi waktu dan produktivitas dan mutu ayam meningkat (s/d 300\%); (5) kesehatan ternak babi dan anjing meningkat, 6) aneka hasil kerajinan dari pengolahan sisa/limbah plastik berupa asbak, tempat tisu, tas, keranjangsayur dan lain sebagainya dan 7) ternak ikan dan aneka sayuran hasil intgerasi dalam sistem aquaponik .

\section{Saran}

1. Perlunya pendampingan lanjutan oleh PPl atau tenaga swadaya dari kelompok yang telah dilatih.

2. Teknologi tepat guna berbasis pekarangan dengan pola integrasi usaha sebaiknya direplikasi juga dihamparan lainnya sehingga selain usaha tani ternak, serta pengolahan limbah 
anorganik seperti plastik dan lainnya sehingga lebih ramah lingkungan, tentu saja adanya peningkatan ketersediaan produk pangan/sayuran atau lainnyayang lebih sehat.

\section{DAFTAR PUSTAKA}

Ndoen, B. 2009. Aplikasi Teknologi Pengolahan Limbah Pada Usaha Penggemukan Sapi. Makalah Program KKU Dirjen Dikti. 24 -26 Juli 2009. Laporan Kegiatan LPM Undana , 2010. Pengolahan Limbah Ternak Menjadi Bio-Gas dan Pupuk Organik Padat dan

Cair. Kegiatan Penyuluhan Di Desa Oefafi Kec. Kupang timur. Kab. Kupang. Laporan kegiatan LPPM Politani Undana.

Nono, Obed H, P. Kune dan B.Ndoen. 2012. PKM Kepada Kelompok Tani Ternak. Laporan Pelaksanaan di Kecamatan Kupang Tengah Kabupaten Kupang. Laporan Program IbM LPPM Undana

, B. Ndoen, D.B.Osa dan M.Yunus, 2002. Penumbuhan Jiwa Wirausaha Mahasiswa Melalui Program Kuliah Kerja Usaha Pada Usaha Penggemukkan Sapi di kabupaten Sumba Timur. Laporan Program Pengembangan Kewirausahaan di Perguruan Tinggi.

Siregar, N.N dan Sri wahyuni, 2018. Optimalisasi Pemanfaatan Lahan Pekarangan sebagai Sumber Pangan. Jurnal Amaliah : Jurnal Pengabdian Kepada Masyarakat Volume 2 Nomor 1 Mei 2018. Univ. Muslim Nusantara Al Wasliyah. https://www.neliti.com/id/publications/279281/ optimalisasi-pemanfaatan-lahan-pekarangan-sebagai-sumber-pangan

Anonymous, 2020 . Manfaat aquaponik. https://id.scribd.com/document/363869209/ Manfaataquaponik. diakses 31 mei 2020 